\title{
Unesterified Cholesterol Accumulation in Late Endosomes/ Lysosomes Causes Neurodegeneration and Is Prevented by Driving Cholesterol Export from This Compartment
}

\author{
Amal Aqul, ${ }^{1}$ Benny Liu, ${ }^{2}$ Charina M. Ramirez, ${ }^{1}$ Andrew A. Pieper,,${ }^{3,4}$ Sandi Jo Estill, ${ }^{4}$ Dennis K. Burns, ${ }^{5}$ Bing Liu, ${ }^{6}$ \\ Joyce J. Repa, ${ }^{2,6}$ Stephen D. Turley, ${ }^{2}$ and John M. Dietschy ${ }^{2}$ \\ Departments of ${ }^{1}$ Pediatrics, ${ }^{2}$ Internal Medicine, ${ }^{3}$ Psychiatry, ${ }^{4}$ Biochemistry, ${ }^{5}$ Pathology, and ${ }^{6}$ Physiology, The University of Texas Southwestern Medical \\ School, Dallas, Texas 75390
}

\begin{abstract}
While unesterified cholesterol (C) is essential for remodeling neuronal plasma membranes, its role in certain neurodegenerative disorders remains poorly defined. Uptake of sterol from pericellular fluid requires processing that involves two lysosomal proteins, lysosomal acid lipase, which hydrolyzes C esters, and NPC1 (Niemann-Pick type C1). In systemic tissues, inactivation of either protein led to sterol accumulation and cell death, but in the brain, inactivation of only NPC1 caused C sequestration and neurodegeneration. When injected into the CNS of the $n p c 1^{-1-}$ mouse, 2-hydroxypropyl- $\beta$-cyclodextrin (HP- $\beta$-CD), a compound known to prevent this $\mathrm{C}$ accumulation, diffused throughout the brain and was excreted with a $t_{1 / 2}$ of $6.5 \mathrm{~h}$. This agent caused suppression of $C$ synthesis, elevation of $C$ esters, suppression of sterol regulatory-binding protein 2 (SREBP2) target genes, and activation of liver X receptor-controlled genes. These findings indicated that HP- $\beta$-CD promoted movement of the sequestered $\mathrm{C}$ from lysosomes to the metabolically active pool of $\mathrm{C}$ in the cytosolic compartment of cells in the CNS. The $\mathrm{ED}_{50}$ for this agent in the brain was $\sim 0.5 \mathrm{mg} / \mathrm{kg}$, and the therapeutic effect lasted $>7 \mathrm{~d}$. Continuous infusion of HP- $\beta$-CD into the ventricular system of $n p c 1^{-1-}$ animals between 3 and 7 weeks of age normalized the biochemical abnormalities and completely prevented the expected neurodegeneration. These studies support the concept that neurons continuously acquire $\mathrm{C}$ from interstitial fluid to permit plasma membrane turnover and remodeling. Inactivation of NPC1 leads to lysosomal C sequestration and neurodegeneration, but this is prevented by the continuous, direct administration of HP- $\beta$-CD into the CNS.
\end{abstract}

\section{Introduction}

Unesterified cholesterol (C) is an essential component of plasma membranes. Importantly, these molecules are "turned over" daily at rates varying, in the mouse, from $8 \%$ per day in cells of systemic organs to an estimated $>20 \%$ per day in neurons of the CNS (Dietschy and Turley, 2004). Given these high rates of turnover, all cells must have constant supplies of new $\mathrm{C}$ to replace those molecules lost to the pericellular fluid. As illustrated in Figure 1, however, the sources of this $\mathrm{C}$ are different for cells of systemic organs (Fig. 1A) and neurons within the mature CNS (Fig. $1 B$ ). Systemic tissues have both high rates of synthesis (Fig. $1 \mathrm{Ae}$ ) and access to $\mathrm{C}$ and cholesteryl ester (CE) carried in the plasma lipoproteins, low-density lipoprotein (LDL), chylomi-

\footnotetext{
Received March 15, 2011; revised April 26, 2011; accepted May 3, 2011.

Author contributions: J.M.D., A.A., Be.L., C.M.R., A.P., J.J.R., and S.D.T. designed research;A.A., Be.L., C.M.R., A.P., S.E., D.K.B., Bi.L., J.J.R., and S.D.T. performed research; J.M.D., A.A., Be.L., C.M.R., D.K.B., Bi.L., J.J.R., and S.D.T. analyzed data; J.M.D., A.A., and S.D.T. wrote the paper.

This work was supported by U.S. Public Health Service Grant R01-HL09610 (J.M.D., S.D.T.) and by grants from the Moss Heart Fund (J.M.D.) and the Ara Parseghian Medical Research Foundation (Be.L., C.M.R., J.J.R.). We acknowledge the excellent technical assistance of Carolyn Crumpton, Taylor Allison, Mario Saucedo, and Jennifer Burg. We also thank Dr. Peter Pentchev for supplying the original $n p c 1^{+/-}$breeding stock and Drs. Gregory Grabowski and Hong Du for the $\mathrm{Ial}^{+/-}$breeding stock.

The authors declare no conflicts of interest.

John M. Dietschy, University of Texas Southwestern Medical School, 5323 Harry Hines Boulevard, Dallas, TX 75390-9151.E-mail: john.dietschy@utsouthwestern.edu.

DOI:10.1523/JNEUROSCI.1317-11.2011

Copyright $\odot 2011$ the authors $\quad 0270-6474 / 11 / 319404-10 \$ 15.00 / 0$
}

crons, and very-low-density lipoproteins (Dietschy et al., 1993). After processing through the late endosomal/lysosomal (E/L) compartment, the $\mathrm{C}$ generated from these lipoproteins (Fig. $1 A d)$ joins newly synthesized sterol $(e)$ in a metabolically active pool in the cytosolic compartment that supports continuous turnover of $\mathrm{C}$ in the plasma membrane $(g)$. In contrast, while neurons have high rates of $\mathrm{C}$ turnover, they have no access to $\mathrm{C}$ or CE from plasma lipoproteins (Cavender et al., 1995; Quan et al., 2003), and have low rates of synthesis (Nieweg et al., 2009). Several in vitro observations provide a possible explanation for this conundrum. Axon growth in neurons requires an extracellular source of sterol, likely C bound to apolipoprotein E (Posse De Chaves et al., 2000; Hayashi et al., 2004). Furthermore, synaptogenesis in vitro also requires an outside source of $\mathrm{C}$ and, again, this is a glial-derived apoE-C complex (Mauch et al., 2001).

Such observations led to the model illustrated in Figure $1 B$, where it is postulated that the rate of sterol synthesis in neurons (Fig. $1 B j$ ) is insufficient to promote axon growth and synapse formation. Rather, $\mathrm{C}$ and apoE are both synthesized in astrocytes, and this complex is delivered to neurons through the interstitial fluid, taken up by receptor-mediated endocytosis, and processed through the late E/L compartment. Importantly, secretion of the apoE-C complex from astrocytes is not dependent on the lysosomal protein, NPC1 (Karten et al., 2005), while movement of this $\mathrm{C}$ through the late $\mathrm{E} / \mathrm{L}$ compartment of neurons is dependent on the function of this protein (Karten et al., 2002). Whether this 


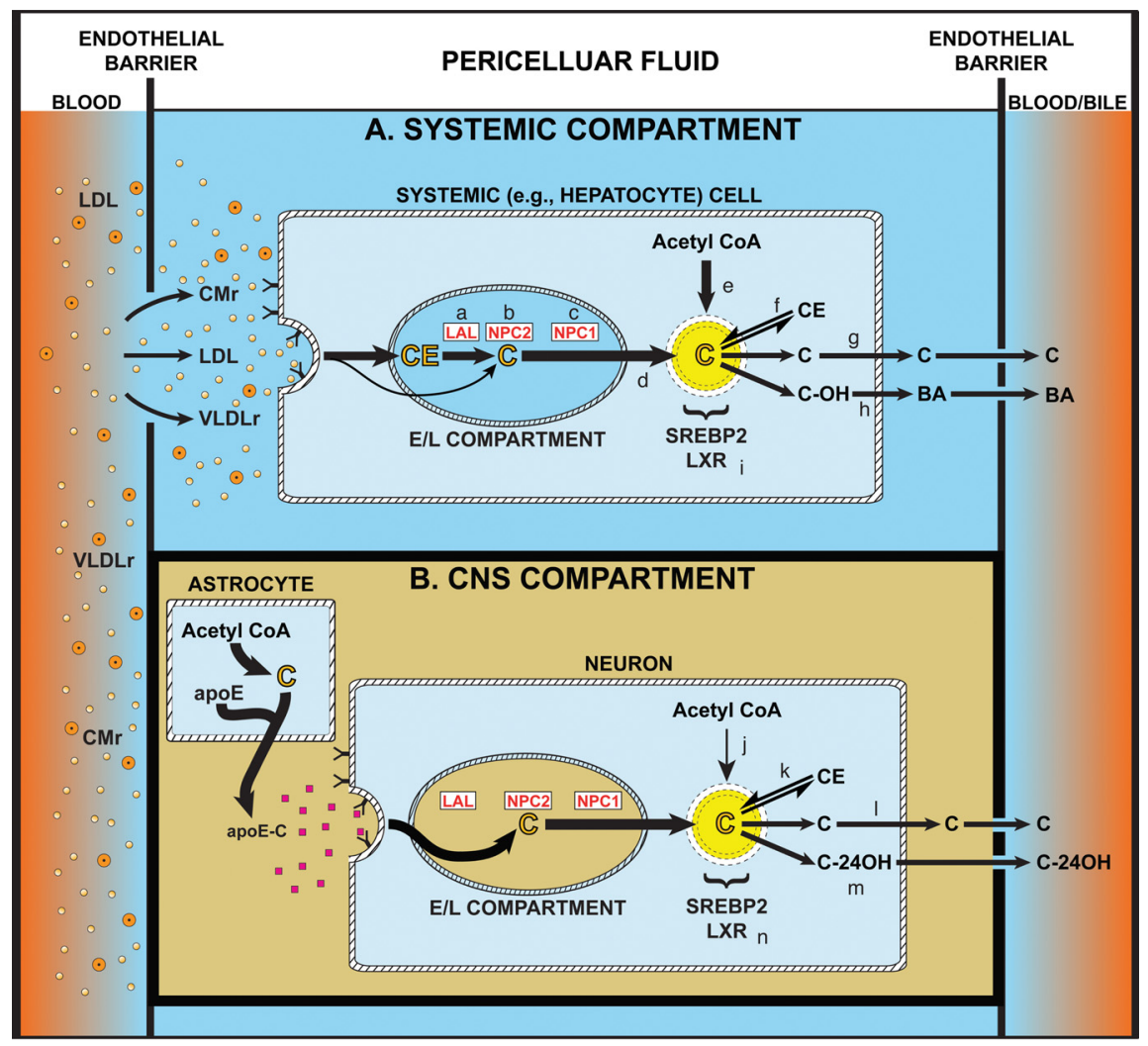

Figure 1. Comparison of cholesterol trafficking through cells of systemic tissues, represented here by liver, and neurons of the CNS. A, The pericellular fluid surrounding cells of systemic organs may contain various lipoproteins including LDL and the remnants of chylomicrons (CMr), and very-low-density lipoproteins (VLDLr). These particles are taken up into cells by receptor-mediated and bulk-phase endocytosis, and delivered into the late $E / L$ compartment of cells where the CE is metabolized to C by LAL (a). This C then interacts sequentially with NPC2 (b) and NPC1 (c) before reaching the limiting membrane and exiting the E/L compartment (d) to join newly synthesized C (e) in a metabolically active pool in the cytoplasmic compartment. The size of this pool is closely regulated by the sterol-sensing transcript factors, SREBP2 and LXR (i), and, depending on the cell type, this ( may be re-esterified (f), used for turnover and remodeling of the plasma membrane ( $\mathbf{g}$ ), or hydroxylated to an oxysterol (h) and, in the liver, to bile acid (BA). The magnitude of sterol flow through each systemic organ is determined, in part, by the ability of the various lipoprotein fractions to penetrate the endothelial barrier, described by the reflection coefficient, $\partial$, separating the blood from the pericellular fluid. $\boldsymbol{B}$, The situation in the CNS is quite different, however, since the endothelial barrier is impermeable to plasma lipoproteins. In this compartment it is postulated that $C$ is synthesized by glia, particularly by astrocytes, and carried as a complex with apoE to neurons. Uptake of this ( presumably bypasses the need for LAL so that the sterol interacts directly with NPC2 and NPC1 to move into the metabolically active pool. There it may also be re-esterified (k), used for membrane remodeling and formation/maintenance of dendrites and synapses (I), or metabolized to the oxysterol, 24(S)-hydroxycholesterol (m), for excretion. It should be noted that in both systemic cells and neurons, sudden expansion of the metabolically active pool of C in the cytosolic compartment is associated with suppression of cholesterol synthesis, an increase in the CE concentration, suppression of various SREBP2 target genes, and activation of some genes controlled by LXR. In the young adult mouse, the flow of C through all systemic cells is $\sim 140$ $\mathrm{mg} \cdot \mathrm{kg}^{-1} \cdot \mathrm{d}^{-1}$, while flow across the CNS is $\sim 1.4 \mathrm{mg} \cdot \mathrm{kg}^{-1} \cdot \mathrm{d}^{-1}$ (Dietschy and Turley, 2004).

model is applicable to the brain in vivo, and whether disordered processing of $\mathrm{C}$ through this pathway might lead to some forms of neurodegeneration such as that seen in Niemann-Pick type C (NPC) disease, continues to be debated (Carstea et al., 1997; Pfrieger, 2003). The current studies were undertaken to explore these unresolved issues. The first experiment examines whether cells of the brain take up $\mathrm{C}$ and/or $\mathrm{CE}$, and whether $\mathrm{C}$ sequestration in neurons is associated with neurodegeneration. The second study examines whether agents like 2-hydroxypropyl- $\beta$-cyclodextrin (HP- $\beta$-CD), which prevent $\mathrm{C}$ sequestration in systemic cells in NPC disease, also act in the CNS. Finally, the third set of investigations explores whether the continuous administration of HP- $\beta$-CD into the brain prevents the neurodegeneration expected in this disorder.

\section{Materials and Methods}

Animals and diets. Control ( $n p c 1^{+/+}$and $\left.l a l^{+/+}\right)$and homozygous ( $n p c 1^{-/-}$ and $\mathrm{lal}^{-1-}$ ) mutant mice were generated from heterozygous breeding stock on a pure $\mathrm{BALB} / \mathrm{c}(n p c 1)$ or $\mathrm{FVB} / \mathrm{N}$ (lal) background (Loftus et al., 1997; Du et al., 2008). Pups were weaned and genotyped at 19-21 d of age. The details of animal housing and diets have been described previously (Liu et al., 2007). All mice were weaned to a basal low-cholesterol rodent diet (7001, Harlan Teklad). There were comparable numbers of males and females in each group. All experimental protocols were approved by the Institutional Animal Care and Use Committee of The University of Texas Southwestern Medical School.

Cyclodextrin administration. The dose and route of administration of cyclodextrin, as well as the period of treatment, varied with the design of each experiment. Mice were treated with $\mathrm{HP}-\beta-\mathrm{CD}$ by systemic administration (subcutaneous injection at the scruff of the neck), or by CNS administration (intracerebroventricular injections into the left ventricle). For systemic administration, HP- $\beta$-CD was provided as a $20 \%(\mathrm{w} / \mathrm{v})$ solution in isotonic saline, while saline alone served as the control in matched mice. For CNS administration, HP- $\beta$-CD was provided as either a $17.4 \%$ or a $35 \%(\mathrm{w} / \mathrm{v})$ solution in artificial CSF (aCSF). The aCSF contained the following (in $\mathrm{mm}$ ): $128 \mathrm{NaCl}, 2.5 \mathrm{KCl}, 0.95 \mathrm{CaCl}_{2}, 1.9$ $\mathrm{MgCl}_{2}$, and served as the control. For one series of studies, mice received a single, acute intracerebroventricular injection of $\mathrm{HP}-\beta-\mathrm{CD}$ or aCSF; in another study, 21-d-old mice were implanted with osmotic minipumps (Alzet 1004), to deliver HP- $\beta$-CD or aCSF to the left lateral ventricle ( $3 \mathrm{~mm}$ deep to the pial surface, $0.3 \mathrm{~mm}$ anteroposterior to bregma, and 1.3 $\mathrm{mm}$ lateral to midline) (Pieper et al., 2005) at an infusion rate of $0.11 \mu \mathrm{l} / \mathrm{h}$ for $28 \mathrm{~d}$. The route, dose, number of injections, and period of treatment varied among experiments, and full details are provided in each figure legend. All doses of HP- $\beta$-CD given either systemically or intracerebroventricularly are presented as milligrams/kilogram of animal body weight.

Cyclodextrin pharmacokinetics. Whole-body and brain HP- $\beta-\mathrm{CD}$ clearance was measured in 49 -d-old $n p c 1^{+/+}$and $n p c 1^{-1-}$ mice using ${ }^{14} \mathrm{C}$-labeled HP- $\beta$-CD as described previously (Liu et al., 2010). The stock $\left[{ }^{14} \mathrm{C}\right] \mathrm{HP}-\beta-\mathrm{CD}$ solution contained $1.0 \mathrm{mCi}$ in $1.0 \mathrm{ml}$ of water. For whole-body clearance, aliquots of the stock solution were added to a $20 \%(\mathrm{w} / \mathrm{v})$ solution of nonradiolabeled HP- $\beta$ $\mathrm{CD}$, giving $\sim 10,000 \mathrm{cpm} / \mu \mathrm{l}$. The mice were given a subcutaneous injection of the $\left[{ }^{14} \mathrm{C}\right] \mathrm{HP}-\beta$-CD solution $(4000 \mathrm{mg} / \mathrm{kg})$ at the scruff of the neck, and then studied at various time points. The total body counts recovered from animals terminated at each time point were normalized to body weight, and then expressed as a percentage of the normalized counts that were present in the tissues of the "zero time" control animals. These data were taken as a measure of the "whole-animal" turnover rate of systemic HP- $\beta$-CD. In a similar fashion, the turnover rate of HP$\beta$-CD specifically in the brain was measured. Aliquots of the stock solution of $\left[{ }^{14} \mathrm{C}\right] \mathrm{HP}-\beta$-CD were added to a $40 \%(\mathrm{w} / \mathrm{v})$ solution of nonradiolabeled HP- $\beta$-CD, giving $\sim 1.19 \mu \mathrm{Ci} / \mu$ l. The animals were administered $2 \mu \mathrm{l}$ via an intracerebroventricular injection. The needle was left in place for $20 \mathrm{~min}$ to minimize any loss of the injected solution. The mice were studied at different time intervals, with the ones terminated at the end of the injection serving as "zero time" controls. Following anesthesia and exsanguination, the skin was removed and the head with the spine was dissected as a whole unit to avoid any leakage of CSF. The head 


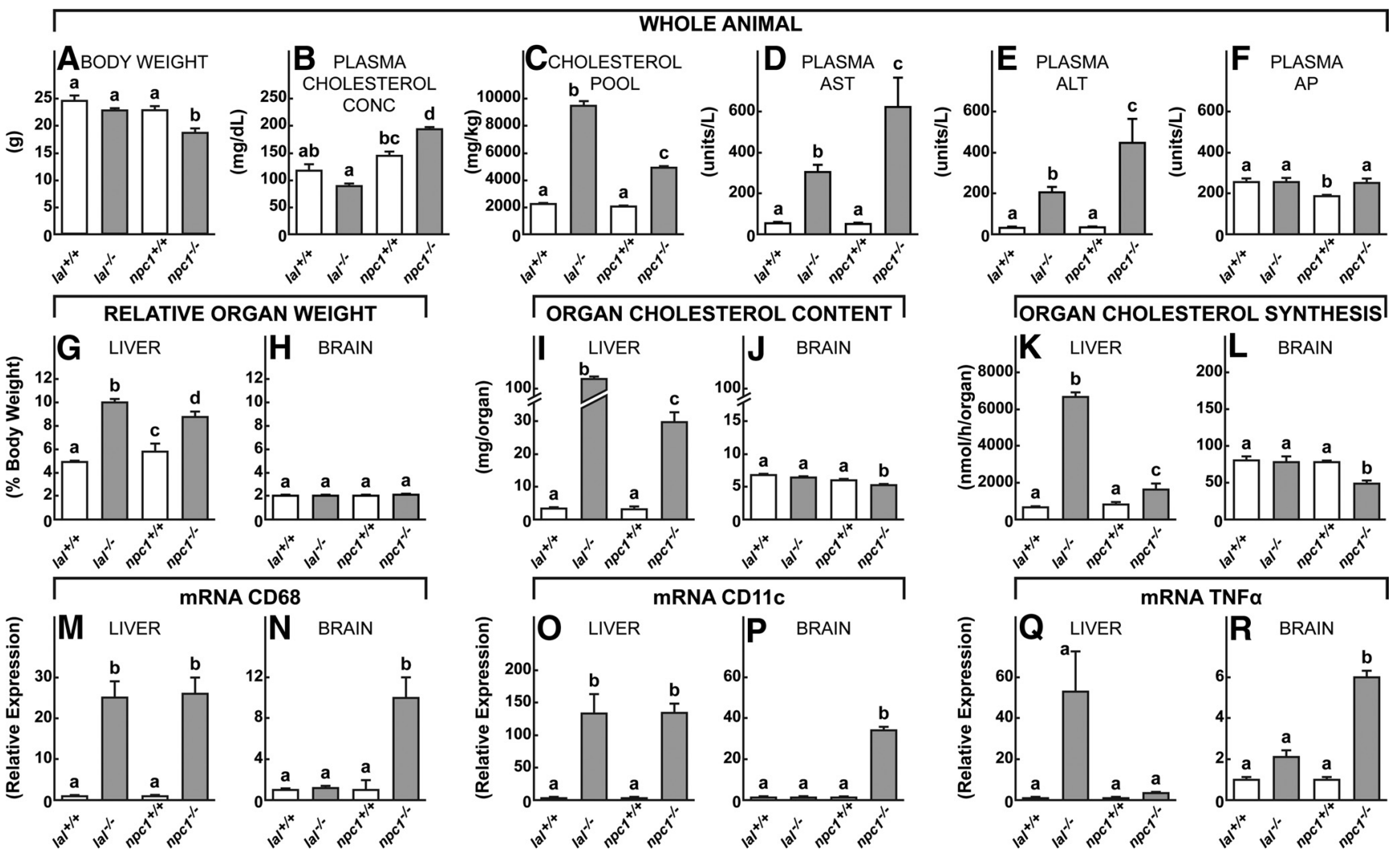

Figure 2. Comparison of various anatomical, metabolic, inflammatory, and clinical parameters in $|a|^{-1-}$ and $n p c 1^{-1-}$ mice. A-F, Utilizing $49-\mathrm{d}-\left.0|\mathrm{ld}| a\right|^{+/+},|a|^{-/-}, n p c 1^{+/+}$, and $n p c 1^{-/-}$ animals, whole-body weights $(\boldsymbol{A})$ and total cholesterol pools $(\boldsymbol{C})$, along with plasma total cholesterol concentrations $(\boldsymbol{B})$, were assessed, as were the various liver function tests, aspartate aminotransferase (AST), alanine aminotransferase (ALT), and alkaline phosphatase (AP) $(\boldsymbol{D}-\boldsymbol{F}) . \mathbf{G}-\boldsymbol{L}$, Relative liver $(\boldsymbol{G})$ and brain $(\boldsymbol{H})$ weights were determined, and whole-organ total cholesterol contents $(\boldsymbol{I}, \boldsymbol{J})$ and synthesis rates $(\boldsymbol{K}, \boldsymbol{L})$ were measured. $\boldsymbol{M}-\boldsymbol{R}$, Inflammation in these two organs was assessed by measuring mRNA expression for the markers $(D 68(\boldsymbol{M}, \boldsymbol{N}), \mathrm{CD} 11 \mathrm{C}(\boldsymbol{O}, \boldsymbol{P})$, and TNF $\alpha$ $(\boldsymbol{Q}, \boldsymbol{R})$. These mRNA values are all expressed relative to the values found in the control $/\left.a\right|^{+/+}$and $n p c 1^{+/+}$mice. Each column shows the mean \pm 1 SEM $(n=6$ animals in each group). Significant differences $(p<0.05)$ among the groups are indicated by different letters.

and spine were saponified in $1 \mathrm{~N} \mathrm{NaOH}$ and vigorously stirred over $30 \mathrm{~h}$. The digested tissue was then transferred into a $100 \mathrm{ml}$ flask and brought to volume with $1 \mathrm{~N} \mathrm{NaOH}$. Duplicate $0.5 \mathrm{ml}$ aliquots were transferred into glass counting vials and neutralized with 0.5 $\mathrm{ml}$ of $1 \mathrm{~N} \mathrm{HCl}$, following which $15 \mathrm{ml}$ of Ecolite (ICN Biomedicals) was added. These data were used to calculate the proportion of the administered dose of $\left[{ }^{14} \mathrm{C}\right] \mathrm{HP}-\beta-\mathrm{CD}$ cleared from the CNS over each respective time interval.

Tissue cholesterol concentrations, rates of cholesterol and fatty acid synthesis, plasma cholesterol levels, liver function tests, and lifespan measurement. The methods used for measuring either tissue concentrations of total or of esterified and unesterified cholesterol have been described previously (Beltroy et al., 2007). The rates of cholesterol and fatty acid synthesis were measured in vivo using $\left[{ }^{3} \mathrm{H}\right]$ water as previously described (Repa et al., 2005), except that the amount of $\left[{ }^{3} \mathrm{H}\right]$ water given in the acute brain injection studies was increased from the customary $2 \mathrm{mCi}$ to $5 \mathrm{mCi} / \mathrm{g}$ body weight. This was done to raise the specific activity of the CSF water to a level that would permit readily measurable rates of incorporation of the labeled water into sterols in the various regions of the brain. To obtain rates of cholesterol synthesis in the whole brain, the rate in each region $\left(\mathrm{nmol} \cdot \mathrm{h}^{-1} \cdot \mathrm{g}^{-1}\right)$ was multiplied by the
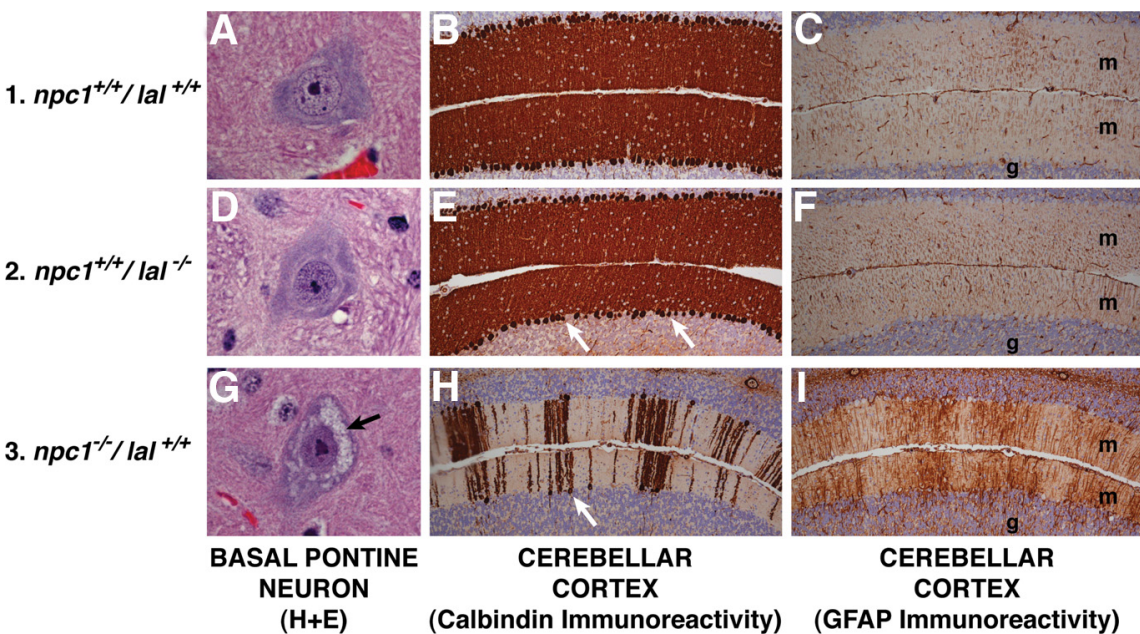

Figure 3. Representative histological sections of basal pontine neurons and the anterior-superior cerebellar vermis of control, $n p C 1^{+/+} / \mid a l^{+/+}$mice, and of $/\left.a\right|^{-1-}$ and $n p c 1^{-1-}$ animals. A, D, G, Typical appearance of basal pontine neurons in these three groups of mice. $B, E, H$, Calbindin immunoreactivity in sections of the anterior-superior cerebellar vermis to illustrate the morphology of the Purkinje cell network. $C, F, I$, GFAP immunoreactivity in the anterior-superior vermis illustrating variation in the degree of activation of Bergmann glia in these same animals. The arrow in $\mathbf{G}$ points to vesicular cytoplasmic lipid collections, while the arrows in $\boldsymbol{E}$ and $\boldsymbol{H}$ point to perikarya of Purkinje cells in the cerebellum. The molecular $(\mathrm{m})$ and granular $(\mathrm{g})$ layers of the cerebellum are identified. H\&E represents hematoxylin and eosin staining.

region weight and summed. Plasma cholesterol levels and the activities of aspartate aminotransferase and alanine aminotransferase were determined as described previously (Beltroy et al., 2007). Lifespan was measured as detailed previously (Liu et al., 2008). 

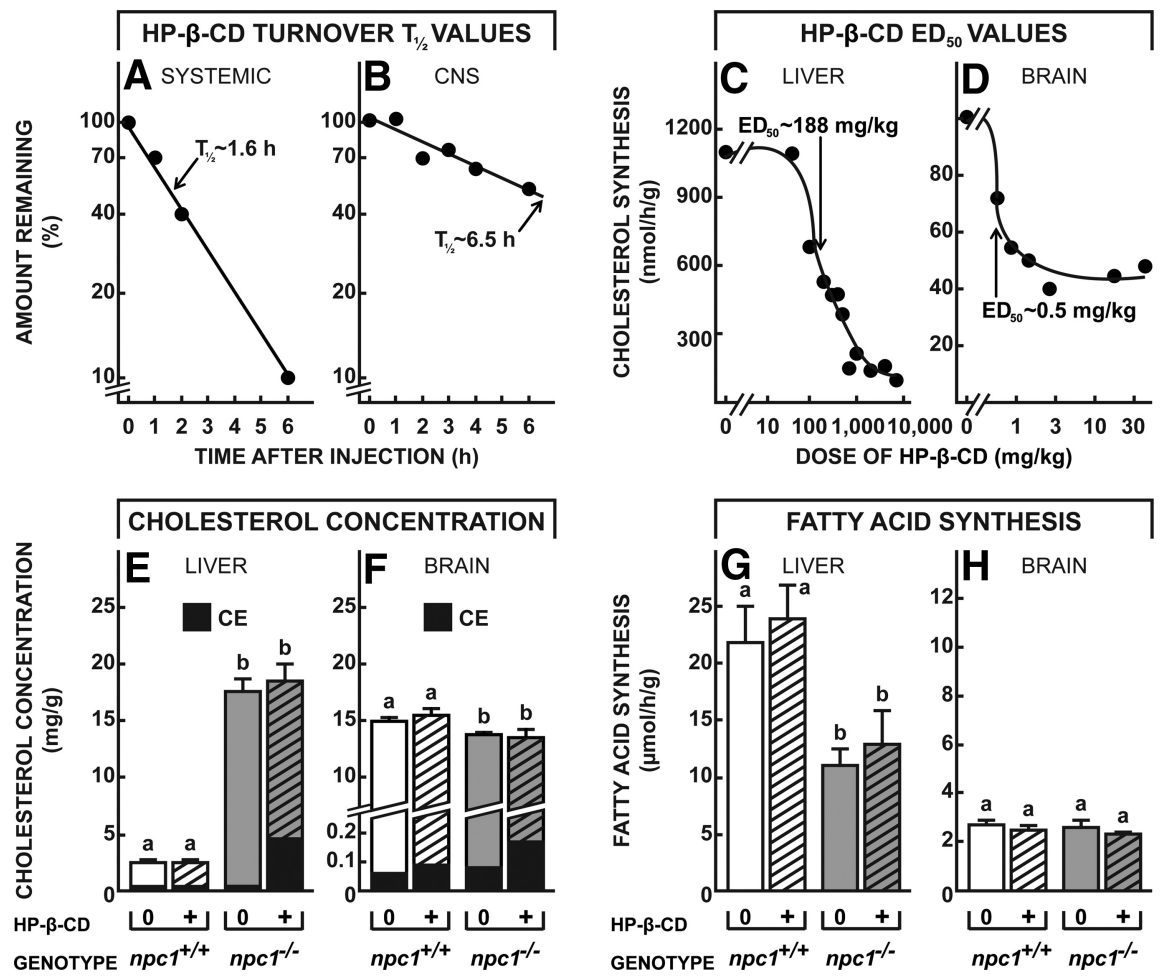

Figure 4. Time course for the clearance of HP- $\beta$-CD from the CNS, and its effects on rates of sterol synthesis and CE formation in the brain. $A, B$, The $49-\mathrm{d}-0$ ld $n p c 1^{+/+}$and $n p c 1^{-/-}$mice were injected at time 0 with either a subcutaneous $(4000 \mathrm{mg} / \mathrm{kg})(\boldsymbol{A})$ or an intracerebroventricular $(40 \mathrm{mg} / \mathrm{kg})(B)$ dose of ${ }^{14} \mathrm{C}$-labeled HP- $\beta$-CD. Animals were then killed at different intervals, and the total body content $(n=20)$ or total CNS content $(n=20)$ of HP- $\beta$-CD was determined. The calculated $t / 2$ values for the whole body or whole CNS are shown. $C, D$, The 49 -d-old $n p c 1^{-1-}$ mice were administered varying doses of HP- $\beta$-CD either subcutaneously $(\boldsymbol{C})$ or intracerebroventricularly $(\boldsymbol{D})$, and $24 \mathrm{~h}$ later, rates of cholesterol synthesis were measured in the liver $(n=68)$ and brain $(n=12)$. Sigmoid curves were fitted to these experimental data to yield the $\log _{10} \mathrm{ED}_{50}$ values, and these were converted to the dose of cyclodextrin administered, either systemically or into the brain, that resulted in $50 \%$ inhibition of synthesis. $\boldsymbol{E}, \boldsymbol{F}$, The 49-d-old $n p C 1^{+/+}$and $n p c 1^{-1-}$ animals $(n=4-6$ in each group) were administered either a subcutaneous $(4000 \mathrm{mg} / \mathrm{kg})(\boldsymbol{E})$ or an intracerebroventricular $(35 \mathrm{mg} / \mathrm{kg})(\boldsymbol{F})$ dose of $\mathrm{HP}-\beta-\mathrm{CD}$, and $24 \mathrm{~h}$ later, the level of $\mathrm{C}$ and $\mathrm{CE}$ in the liver and brain of each animal was determined. $\mathbf{G}, \boldsymbol{H}$, Similarly treated groups of $n p \mathrm{C}^{+/+}$and $n p c 1^{-/-}$animals $(n=4-6$ in each group) were used to measure rates of fatty acid synthesis $24 \mathrm{~h}$ after administration of the HP- $\beta$-CD. Significant differences $(p<0.05)$ among groups are indicated by different letters.

Gene expression. Under deep anesthesia, mice were exsanguinated, and the brain and liver were removed and frozen in liquid nitrogen before RNA isolation. The mRNA levels for a constellation of genes were measured by quantitative real-time PCR using SYBR Green chemistry and an Applied Biosciences 7900HT instrument (Kurrasch et al., 2004). mRNA levels were determined for brain and liver tissues from individual animals and are expressed relative to the invariate housekeeping gene, cyclophilin. Primer sequences are available upon request (J.J.R.) (Repa et al., 2007).

Brain histology and immunohistochemistry. Brains were immersionfixed in $10 \%(\mathrm{v} / \mathrm{v})$ buffered formalin. The details of the methods for preparation of various brain regions for histology and the counting of Purkinje cells on H\&E sections, as well as the immunostaining techniques used have been given previously (Repa et al., 2007).

Data analysis. All data are presented as a mean \pm 1 SEM. Differences between means of groups were tested for significance $(p<0.05)$ using one-way ANOVA, followed by the Newman-Keuls multiple-comparisons test (GraphPad Software). Significant differences between groups are designated by different letters. To establish the $\mathrm{ED}_{50}$ values, individual data points were fitted to sigmoid curves and analyzed using the $\log _{10}$ inhibitor versus response equation to determine the concentration that provokes a response equal to $50 \%$.

\section{Results}

C and CE uptake by systemic and CNS cells

The first set of experiments tested the hypothesis that while cells of systemic organs take up lipoproteins containing both $\mathrm{C}$ and $\mathrm{CE}$ for processing through the late E/L compartment, cells of the CNS should have access only to $\mathrm{C}$, presumably carried on apoE, as suggested in Figure $1 B$. To explore this issue, mutant animals were used that lacked either lysosomal acid lipase (LAL) or NPC1 activity on the assumption that systemic tissues like the liver would manifest sterol sequestration and cell death when the function of either protein was deleted, while nerve cells in the CNS would manifest such sequestration only when NPC1 function was deleted. The findings in liver, a systemic tissue, were contrasted with those in brain throughout these experiments. In these 49 -d-old animals, there were no differences in body weight (Fig. 2A) or plasma total cholesterol concentration (Fig. $2 B$ ) in the lal $^{-1-}$ mice, while the $n p c 1^{-1-}$ animals did weigh less and had hypercholesterolemia when compared with controls. Nevertheless, both groups had markedly expanded whole-animal total cholesterol pools, i.e., the milligrams of cholesterol per kilogram of body weight (Fig. 2C), and both manifested significant liver damage as indicated by elevated liver function tests (Fig. 2D-F).

Importantly, both the $l a l^{-1-}$ and $n p c 1^{-1-}$ mice had significant hepatomegaly (Fig. $2 G$ ), while relative brain weight was unchanged (Fig. $2 H$ ). The pool of sequestered cholesterol in the liver of the $\mathrm{lal}^{-1-}$ mice was elevated 42 -fold, $92 \%$ of which was CE, and was increased 11-fold in the $n p c 1^{-/-}$mice, all of which was $C$ (Fig. 2I). In contrast, the pool of cholesterol was unchanged in the brain of the animals lacking LAL function, but was reduced slightly in the $n p c 1^{-1-}$ mice (Fig. $2 J$ ). This latter finding has been reported previously, and was attributed to the neurodegeneration and partial demyelination seen in these 49-d-old animals (German et al., 2001; Li et al., 2005). Importantly, the rate of $\mathrm{C}$ synthesis, which reflects the magnitude of the defect in the transfer of sterol from the late E/L compartment to the cytosol, was markedly elevated in the liver (Fig. $2 \mathrm{~K}$ ), but not in the brain (Fig. $2 L$ ) of the $l a l^{-1-}$ mice. There was a smaller elevation of synthesis in the liver of the $n p c 1^{-/-}$animals, and a decrease in the brain.

One of the constant features of these lysosomal storage diseases is the associated infiltration/activation of macrophages and microglia in many organs, and, in particular, in liver and brain (Liu et al., 2007; Repa et al., 2007). Thus, importantly, mRNA levels of the inflammatory markers CD68 and CD11c were markedly elevated in the liver of both the $l a l^{-1-}$ and $n p c 1^{-1-}$ mice (Fig. 2M,O), whereas these markers of inflammation were elevated in the brain only of the $n p c 1^{-1-}$ mice (Fig. $2 N, P, R$ ). Together, these findings support the concept that systemic organs like the liver take up both $\mathrm{C}$ and $\mathrm{CE}$ carried in plasma lipoproteins, and, therefore, these tissues sequester $\mathrm{CE}$ or $\mathrm{C}$ when either LAL or NPC1 function, respectively, is deleted. In both cases, this accumulation of sterol in the late E/L compartment of hepato- 
cytes leads to hepatomegaly, inflammation, and liver function abnormalities. In contrast, only the $n p c 1^{-1-}$ mice manifest changes in sterol metabolism and microglial activation in the brain, indicating that $\mathrm{C}$, but not $\mathrm{CE}$, is being taken up and used by cells of the CNS.

\section{Histological appearance of brain in} lal $^{-1-}$ and $n p c 1^{-1-}$ mice

This conclusion was supported by the histological findings observed in the brains of these 49-d-old mice. The control $n \mathrm{pcl}^{+/+} / \mathrm{lal}^{+/+}$mice exhibited normal neuronal morphology throughout the brain with appropriately distributed Nissl substance, as exemplified by the basal pontine neurons (Fig. 3A). Cerebellar calbindin immunoreactivity was normally distributed within Purkinje cell perikarya and dendrites in the overlying molecular layer (Fig. $3 B$ ), while GFAP immunostaining highlighted normal distribution of Bergmann glial cell processes in this same layer (Fig. 3C). In animals lacking LAL function, histological findings were identical to those seen in control mice with normal neuronal morphology (Fig. $3 D)$, Purkinje cell calbindin reactivity (Fig. 3E), and GFAP immunoreactivity (Fig. $3 F$ ). In contrast, there were marked abnormalities in these areas in the $n p c 1^{-1-}$ mice. Neurons throughout the brain, including those in the basal pons (Fig. 3G), contained abundant vesicular, cytoplasmic lipid collections (which stain for C) (Gondré-Lewis et al., 2003; Repa et al., 2007). There was substantial Purkinje cell loss, manifested by a striking decrease in calbindin immunoreactivity in the molecular layer (Fig. $3 H$ ). Adjacent sections revealed irregular zones of increased GFAP immunoreactivity in the molecular layer, reflecting activation of Bergmann glia in the areas of Purkinje cell loss (Fig. 3I). Thus, these histological findings closely reflect the biochemical and mRNA findings in these same groups of animals, and are consistent with the conclusion that $\mathrm{C}$ is sequestered in neurons throughout the brain of the $n \mathrm{pcl}^{-1-}$ mice, and, in some regions like the cerebellum, this accumulation is associated with marked neurodegeneration.

The cyclodextrin, HP- $\beta-C D$, acutely overcomes the block in C export from the late $\mathrm{E} / \mathrm{L}$ compartment of cells in the brain of $n p c 1^{-/-}$mice

If this is the case, then uptake of HP- $\beta$-CD into these neurons through bulk-phase endocytosis should acutely reverse the transport defect, allowing the sequestered $\mathrm{C}$ to flow into the metabolically active pool in the cytosol, as has been described in other tissues. This sudden expansion of the metabolically active cholesterol pool should be signaled by suppression of sterol synthesis, an increase in the level of CE, suppression of SREBP (sterol regulatory-binding protein) target genes, and activation of some liver X receptor (LXR)-controlled genes, as has been well docu- mented in organs like liver, spleen, and other systemic tissues (Fig. 1) (Liu et al., 2009, 2010). However, HP- $\beta$-CD administered systemically has very limited access to the CNS: when given systemically to 49 - $\mathrm{d}$-old mice, the $\mathrm{ED}_{50}$ for $\mathrm{HP}-\beta$ - $\mathrm{CD}$ acting in liver is $\sim 200 \mathrm{mg} / \mathrm{kg}$, but when acting in CNS is $>100,000 \mathrm{mg} / \mathrm{kg}$ (Ramirez et al., 2011). The second set of studies, therefore, was designed to characterize the physiological and biochemical effects of this cyclodextrin when given directly into the brain. Using both $n p c 1^{+/+}$and $n p c 1^{-1-}$ mice, turnover of the cyclodextrin was slower when administered into the CNS than when administered systemically. Following a single subcutaneous, systemic injection $(4000 \mathrm{mg} / \mathrm{kg}), \mathrm{HP}-\beta-\mathrm{CD}$ was rapidly cleared from the body of the mouse into the urine with a $t \frac{1}{2}$ of $\sim 1.6 \mathrm{~h}$ (Fig. 4A). However, following a single injection into the left lateral ventricle of the brain $(40 \mathrm{mg} / \mathrm{kg})$, the compound was cleared from the whole CNS with a $t \frac{1}{2}$ of $\sim 6.5 \mathrm{~h}$ (Fig. $4 B$ ). Of note, the mass of cyclodextrin administered in these two experiments was comparable after accounting for the differences in volumes of distribution in these two experiments, i.e., milligrams per kilogram per milliliter of bulk water $(\mathrm{mg} / \mathrm{ml})$, which was $\sim 232 \mathrm{ml} / \mathrm{kg}$ 

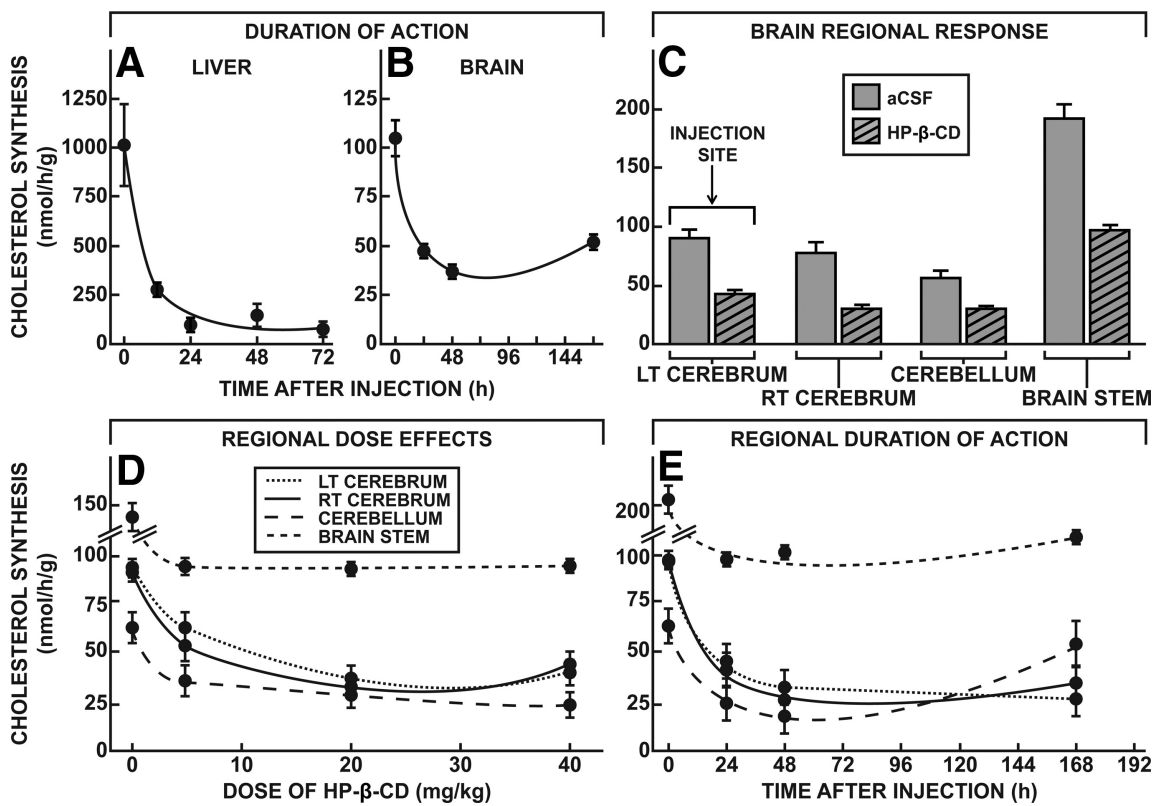

Figure 6. Duration of action and regional effects of $\mathrm{HP}-\beta-\mathrm{CD}$ within the CNS. $A, B$, The $49-\mathrm{d}-\mathrm{old} n p c 1^{-1-}$ mice were injected at time 0 with either a subcutaneous $(4000 \mathrm{mg} / \mathrm{kg})(\boldsymbol{A})$ or an intracerebroventricular $(35 \mathrm{mg} / \mathrm{kg})(\boldsymbol{B})$ dose of HP- $\beta$-CD, and rates of cholesterol synthesis were measured in groups $(n=2-5)$ of these animals at varying times thereafter. $C$, The $49-\mathrm{d}-\mathrm{old} n \mathrm{np} \mathrm{1}^{-/-}$ mice were administered either HP- $\beta$ - $C D(35 \mathrm{mg} / \mathrm{kg})$ or aCSF into the ventricle of the left cerebrum, and rates of $C$ synthesis were measured $24 \mathrm{~h}$ later in different regions of the brain $\left(n=2-5\right.$ in each group). $\boldsymbol{D}$, Groups of $49-\mathrm{d}-\mathrm{old} n p c 1^{-1-}$ mice were given varying doses $(0-40 \mathrm{mg} / \mathrm{kg})$ of $\mathrm{HP}-\beta$-CD by intracerebroventricular injection into the ventricle of the left cerebrum, and rates of C synthesis were measured $24 \mathrm{~h}$ later in the different regions of the brain $\left(n=2-5\right.$ in each group). $\boldsymbol{E}$, The 49-d-old $n p c 1^{-1-}$ animals were administered $\mathrm{HP}-\beta-\mathrm{CD}(35 \mathrm{mg} / \mathrm{kg})$ intracerebroventricularly, and rates of $C$ synthesis were measured at varying times in the major regions of the brain ( $n=2-5$ in each group). Means \pm 1 SEM are shown.

after systemic administration but only $\sim 4.0 \mathrm{ml} / \mathrm{kg}$ after intracerebroventricular dosing.

The most sensitive index of $\mathrm{C}$ flow into the cytosolic compartment is suppression of sterol synthesis (Liu et al., 2009). As shown in Figure $4 C$, when $n \mathrm{pcl}^{-1-}$ mice were administered systemic doses of HP- $\beta$-CD that varied from 0 to $8000 \mathrm{mg} / \mathrm{kg}$, there was nearly complete suppression of sterol synthesis at the higher doses $24 \mathrm{~h}$ later, and the $\mathrm{ED}_{50}$ for this inhibition was $\sim 188 \mathrm{mg} / \mathrm{kg}$. When similar injections were performed in $\mathrm{npcl}^{+/+}$mice, no inhibition of synthesis was seen since such animals have no abnormal pool of $\mathrm{C}$ sequestered in the $\mathrm{E} / \mathrm{L}$ compartment of hepatocytes (data not shown). When the $n p c 1^{-1-}$ mice were administered intracerebroventricular doses of HP- $\beta$-CD that varied from 0 to $35 \mathrm{mg} / \mathrm{kg}$, there was similar inhibition of sterol synthesis within the brain, and the $\mathrm{ED}_{50}$ was $\sim 0.5 \mathrm{mg} / \mathrm{kg}$ (Fig. $4 D$ ). When corrected for the different volumes of distribution, these two $\mathrm{ED}_{50}$ values were similar $(0.13-0.81 \mathrm{mg} / \mathrm{ml}$ or $0.1-0.6$ $\mathrm{mM}$ ) in liver and brain, suggesting that the effect of the cyclodextrin within the late E/L compartment in overcoming the transport defect was quantitatively similar in cells of systemic organs and CNS. Of note, unlike the liver (Fig. $4 C$ ), in the brain, $\sim 40 \%$ of sterol synthesis was not inhibited (Fig. 4D). This finding is similar to that seen in tissues like muscle and fat that take up essentially no lipoprotein sterol and, therefore, have no sequestered pool of $\mathrm{C}$ in the $n p \mathrm{pl}^{-/-}$mice to be released by cyclodextrin (Liu et al., 2010). Conceivably, in the brain, this fraction of sterol synthesis is occurring in a subset of cells that normally take up little or no C associated with apoE.

Another piece of evidence that this cyclodextrin administration acutely expanded the pool of sterol in the cytosol is the rapid conversion of some of this $\mathrm{C}$ to $\mathrm{CE}$ by the cytoplasmic enzyme,
SOAT1 (sterol-O-acyl transferase). Within $24 \mathrm{~h}$ of HP- $\beta$-CD administration systemically, CE levels rose 13-fold in the liver (Fig. $4 E$ ), while after intracerebroventricular administration, $\mathrm{CE}$ levels in the brain increased 2.2-fold (Fig. $4 F$ ). Importantly, cyclodextrin administered intracerebroventricularly to $n p c 1^{+/+}$mice was without effect on CE levels. Furthermore, the administration of cyclodextrin had no affect on fatty acid synthesis, either in the liver or brain, of both the $n p c 1^{+/+}$ and $n p c 1^{-1-}$ animals (Fig. 4G,H). The effect of $H P-\beta-C D$ was specific for C movement.

\section{Expansion of the cytosolic pool of C alters expression of genes controlled by SREBP2 and LXR}

Finally, flow of $\mathrm{C}$ into the metabolically active pool of cells after exposure to HP$\beta-\mathrm{CD}$ is also signaled by marked changes in relative mRNA expression of genes controlled by SREBP2 and LXR. Twentyfour hours after cyclodextrin administration, there was significant suppression of relative mRNA expression for SREBP2, 3-hydroxy-3-methyl-glutaryl (HMG) CoA reductase (RED), HMG CoA synthase (SYN), and low-density lipoprotein receptor (LDLR), but not of PCSK9 (proprotein convertase subtilisin/kexin type 9), in the $n \mathrm{pcl}^{-1-}$ mice (Fig. 5A-E). Similarly, there were significant increases in mRNA levels for ABCA1 and ABCG1, but not for MYLIP (myosin regulatory light chain-interacting protein) (Fig. $5 F-H$ ). Again, there was no effect of this treatment on mRNA levels in the $n p c 1^{+/+}$animals. Of note, HP- $\beta$-CD administration to the $n p c 1^{-1-}$ mice did not alter mRNA levels for NPC2 or SOAT1 (Fig. $5 I, J$ ), or for the fatty acid synthesis-associated genes, SREBP1c and FAS (Fig. $5 K, L$ ). Importantly, mRNA expression of two sterol hydroxylases, CYP27A1 and CYP46A1, and of apoE, that conceivably might play a role in excretion of excess $\mathrm{C}$ from the brain, were unchanged by cyclodextrin administration (Fig. $5 M-O$ ). Since the interval between the administration of the HP- $\beta$-CD and measurement of these mRNA levels was only $24 \mathrm{~h}$, there was partial reduction of expression of the cytokines, CD11c and TNF $\alpha$, but not yet of markers of glial cell number, CD68, CCL3, and GFAP (Fig. 5P-T). Together, these various observations provide unequivocal support for the conclusion that direct administration of HP- $\beta$-CD into the brain of $n \mathrm{pcl}^{-1-}$ mice acutely overcame the lysosomal export defect in cells within the CNS, and allowed the sequestered pool of Cin these cells to rapidly flow into the cytosol for metabolism and excretion, as has been demonstrated in systemic organs (Liu et al., 2009, 2010).

\section{Regional effects and duration of action of HP- $\beta-C D$ administered into the brain}

Two important issues remained concerning the biological effects of acute cyclodextrin administration into the CNS: these included the duration of action of this compound and whether or not the metabolic effects were seen throughout all regions of the brain. Following the single systemic $(4000 \mathrm{mg} / \mathrm{kg})$ or intracere- 
broventricular $(35 \mathrm{mg} / \mathrm{kg})$ administration of $\mathrm{HP}-\beta-\mathrm{CD}$, sterol synthesis in both the liver and whole brain remained suppressed for $>72 \mathrm{~h}$ (Fig. $6 A, B$ ) and, in the CNS, was beginning to return toward normal only after $144 \mathrm{~h}$. This prolonged suppression presumably reflected the expanded pool of CE in the cytosolic compartment of these cells that was slowly hydrolyzed by a neutral cholesteryl esterase.

Since the HP- $\beta$-CD was injected into the lateral ventricle of the left cerebrum, the second question of importance was whether this agent diffused to other regions of the brain and affected C metabolism equally well. Using suppression of sterol synthesis as the measure of therapeutic response, rates of $\mathrm{C}$ synthesis were assessed $24 \mathrm{~h}$ after administration of either aCSF or HP- $\beta$-CD ( $35 \mathrm{mg} / \mathrm{kg})$ into the lateral ventricle of the left cerebrum. As is evident in Figure 6C, the cyclodextrin apparently reached all of the major anatomical regions of the brain, since relative suppression of sterol synthesis was essentially the same in the right cerebrum, cerebellum, and brainstem, as in the left cerebrum, where the HP- $\beta$-CD was administered. Furthermore, the $\mathrm{ED}_{50}$ values for each of these regions were also similar. Twenty-four hours after administration of varying doses of HP- $\beta$-CD intracerebroventricularly, maximum suppression of sterol synthesis was essentially achieved at a dose of $\sim 5 \mathrm{mg} / \mathrm{kg}$ in all four regions of the brain (Fig. $6 D$ ). Furthermore, the duration of action of HP- $\beta$-CD was similar in the cerebral hemispheres, cerebellum, and brainstem, although loss of the therapeutic effect was apparently occurring earlier in the cerebellum than in the other regions (Fig. 6E).

\section{Prevention of neurodegeneration by continuous infusion of $\mathrm{HP}-\boldsymbol{\beta}$-CD into the CNS}

Given the prolonged action of a single systemic dose of HP- $\beta$-CD on sterol metabolism in liver (Fig. 6A), it is not surprising that weekly administration of this compound essentially normalizes $C$ pools throughout the body and prevents liver dysfunction (Ramirez et al., 2011). However, because of limited accessibility of HP- $\beta$-CD to the brain, neurodegeneration is slowed, but not prevented, in animals treated in this manner. Given that the $\mathrm{ED}_{50}$ for the therapeutic effect was $\sim 0.5 \mathrm{mg} / \mathrm{kg}$ (Fig. $4 D$ ), and that the effect was seen throughout the CNS (Fig. $6 C-E$ ), the possibility existed that continuous, combined systemic and intracerebroventricular administration of cyclodextrin might completely prevent the pathological consequences of this lysosomal transport defect in the brain, liver, and other organs. To this end, the third set of studies was undertaken in which groups of $n p c 1^{+/+}$and $n p c 1^{-1-}$ mice were treated weekly with subcutaneous injections and, between 21 and $49 \mathrm{~d}$ of age, with continuous infusions into the lateral ventricle of the left cerebrum. As seen in Figure 7, when control mice were infused with aCSF into the brain and given only saline systemically, neuronal morphology (Fig. 7A), the distribution of Purkinje cells (Fig. $7 B$ ), and the pattern of GFAP
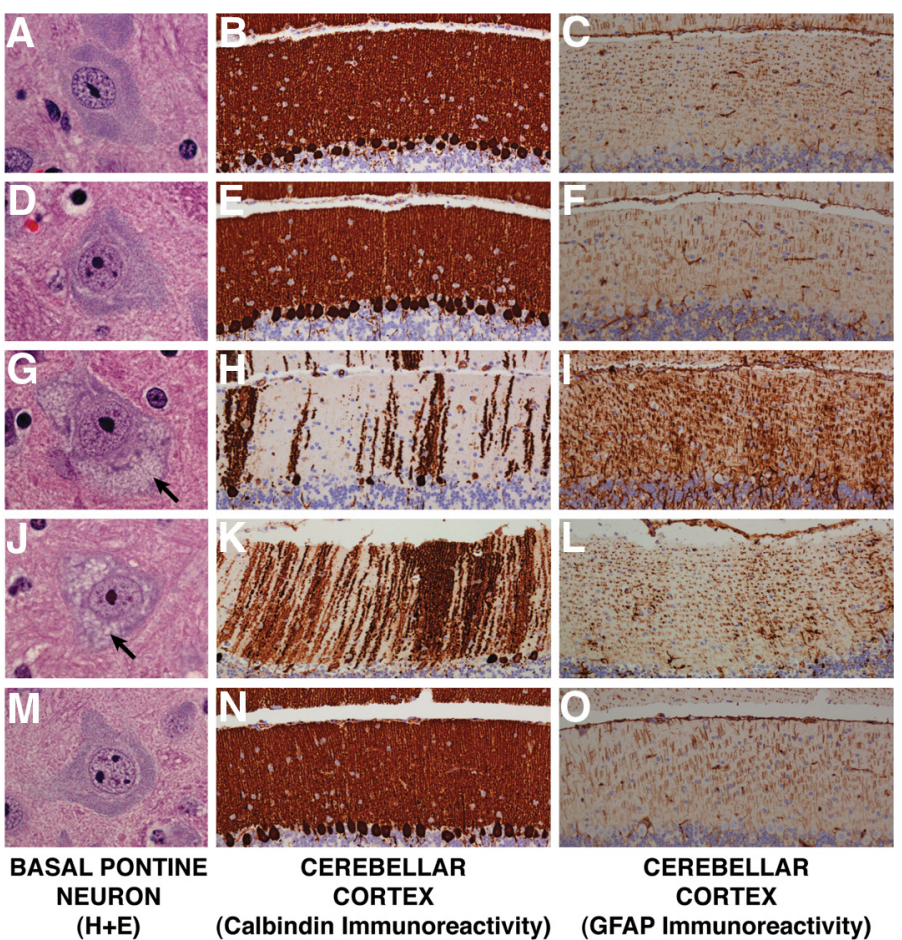

NEURON

(Calbindin Immunoreactivity)

(GFAP Immunoreactivity)
CORTEX
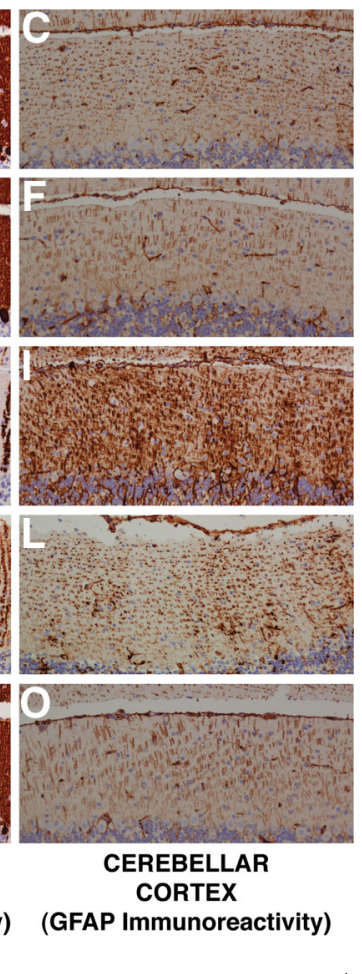

. $+/+$

Figure 7. Representative histological sections of basal pontine neurons and the anterior-superior cerebellar vermis of $n p c 1^{+/+}$
and $n p 1^{-1-}$ mice treated with chronic administration of HP- $\beta$-CD. These animals ( $n=3$ in each group) were given systemic, subcutaneous injections of either saline or HP- $\beta-C D(4000 \mathrm{mg} / \mathrm{kg})$ every $7 \mathrm{~d}$ (beginning at $7 \mathrm{~d}$ of age) along with the continuous intracerebroventricular infusion of either aCSF or HP- $\beta-C D\left(23 \mathrm{mg} \cdot \mathrm{kg}^{-1} \cdot \mathrm{d}^{-1}\right)$ (between the ages of 21 and $49 \mathrm{~d}$ ). All mice were 列

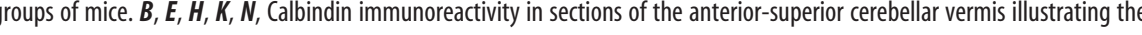
作 showing variation in the degree of activation of Bergmann glia in these same animals. The arrows in $\boldsymbol{G}$ and $\boldsymbol{J}$ point to vesicular

immunoreactivity (Fig. 7C) were normal. Importantly, when HP- $\beta$-CD was administered to such $n p c 1^{+/+}$mice, both into the CNS (23 mg/kg each day) and systemically ( $4000 \mathrm{mg} / \mathrm{kg}$ every $7 \mathrm{~d}$ ), neuronal and cerebellar morphology was also normal (Fig. $7 D-F)$, and indistinguishable from that seen in control animals receiving only placebo treatment. Thus, there was no evidence of an untoward effect of the cyclodextrin in these control animals when given both systemically and as intracerebroventricular infusions.

When $n p c 1^{-/-}$mice were infused with aCSF into the brain and saline systemically, the expected, severe pathological findings were evident at $49 \mathrm{~d}$ of age. There were extensive, vesicular lipid collections in the cytosolic compartment of neuron perikarya (Fig. 7G), marked loss of Purkinje cells in the cerebellum (Fig. $7 \mathrm{H}$ ), and major activation of Bergmann glia in these areas of neurodegeneration (Fig. 7I). Such animals died spontaneously at $\sim 88$ d of age (Ramirez et al., 2010). However, when these mutant mice were treated systemically with weekly doses of HP- $\beta$-CD $(4000 \mathrm{mg} / \mathrm{kg}$ ), but no cyclodextrin was infused into the brain, the loss of Purkinje cells was slowed (Fig. $7 \mathrm{~K}$ ), and the increase in GFAP immunoreactivity was partially blunted (Fig. $7 L$ ). Such animals lived to $\sim 150 \mathrm{~d}$ of age (Ramirez et al., 2010). Finally, however, when $n p c 1^{-1-}$ mice received the HP- $\beta$-CD both systemically and into the brain, the histology in all regions of the CNS was indistinguishable from that seen in the control mice. In particular, there were no vesicular collections of lipid in the nerve cells (Fig. 7M), and Purkinje cell morphology appeared to be fully preserved (Fig. $7 \mathrm{~N}, \mathrm{O}$ ). Purkinje cell number was $98 \pm 3 \%$ 


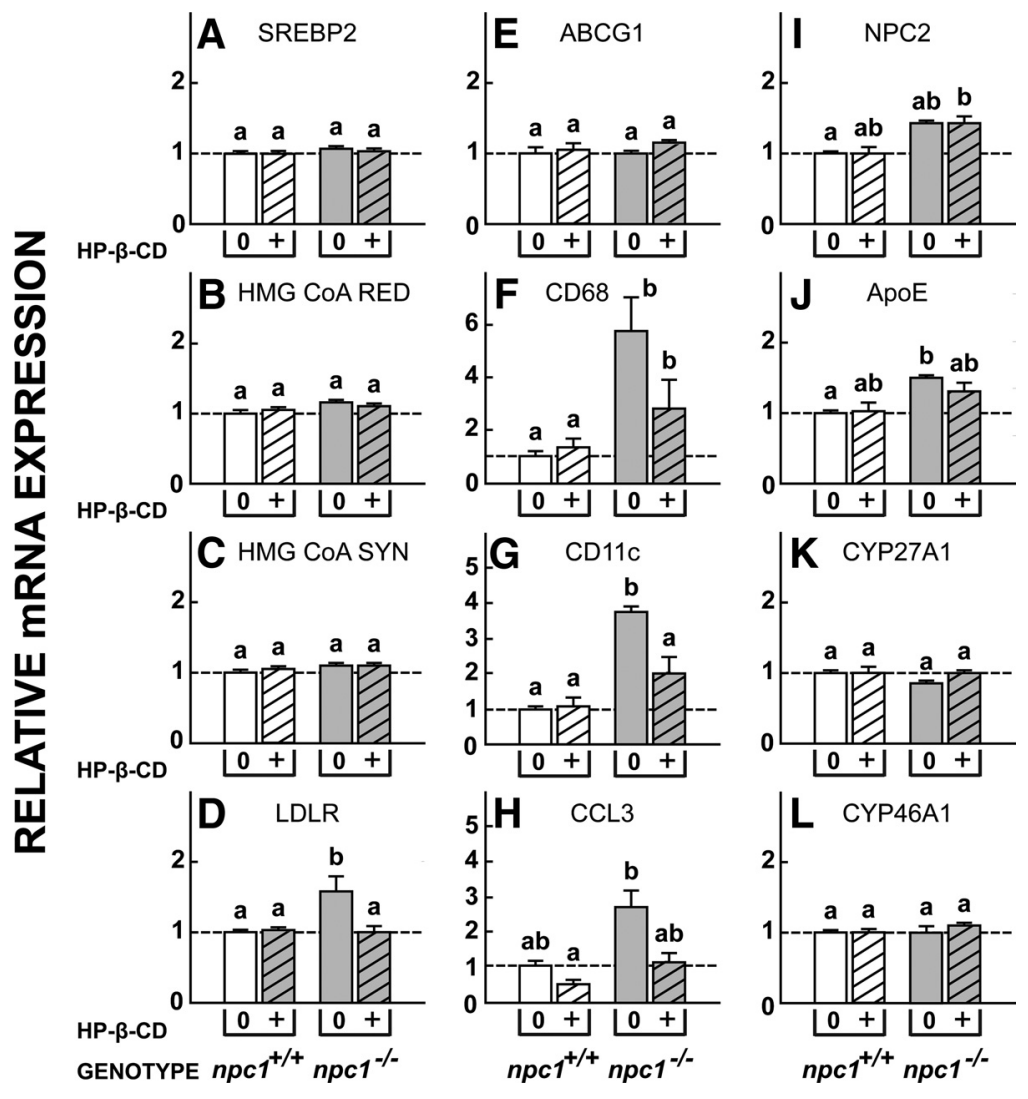

Figure 8. Relative expression of mRNA for a variety of proteins in the $\mathrm{CNS}$ of $n p \mathrm{Cl}^{+/+}$and $n p \mathrm{Cl}^{-1-}$ mice treated chronically with HP- $\beta$-CD. Groups of both $n p c 1^{+/+}$and $n p c 1^{-/-}(n=3$ in each group) mice were given systemic, subcutaneous injections of either saline or HP- $\beta$-CD ( $4000 \mathrm{mg} / \mathrm{kg}$ ) every $7 \mathrm{~d}$ (beginning at $7 \mathrm{~d}$ of age) along with the continuous intracerebroventricular infusion of either aCSF or HP- $\beta$-CD $\left(27 \mathrm{mg} \cdot \mathrm{kg}^{-1} \cdot \mathrm{d}^{-1}\right.$ ) (between 21 and $49 \mathrm{~d}$ of age). All mice were killed for determination of mRNA levels at $49 \mathrm{~d}$ of age. The various mRNAs measured in this study correspond to those previously evaluated in mice receiving a single dose of HP- $\beta$-CD (Fig. 5).

in the $n p c 1^{-1-}$ mice infused with $\mathrm{HP}-\beta-\mathrm{CD}$, compared with the $n p c 1^{+/+}$animals, and body weights of these two groups were not different. Longevity has not yet been determined in mice treated continuously in this manner, since such animals remain clinically well.

Importantly, normalization of mRNA expression of genes controlled by SREBP2 and LXR also supports the conclusion that continuous intracerebroventricular infusion of $\mathrm{HP}-\beta-\mathrm{CD}$ had restored C flow through cells of the brain in these 49 -d-old $n p c 1^{-/-}$mice. While acute administration of $\mathrm{HP}-\beta$-CD to such animals resulted in significant suppression of the mRNA expression of SREBP2, HMG CoA RED, HMG CoA SYN, and LDL, and increased the expression of ABCG1 (Fig. 5), these effects disappeared in the mice receiving continuous therapy with cyclodextrin (Fig. 8, $A-E$ ). In addition, the relative expression of the inflammatory factors CD68, CD11c, and CCL3 also nearly equaled those seen in $n p c 1^{+/+}$animals (Fig. $8 \mathrm{~F}-$ $H$ ). Of note, there was histological evidence of persistent, mild inflammation along the tract of the infusion catheter leading into the left ventricle, even in these animals. This continuous infusion also apparently normalized $\mathrm{C}$ flow through cells of the CNS without elevating mRNA levels for NPC2, apoE, CYP27A1, or, particularly, CYP46A1 (Fig. $8 I-L$ ). These mRNA levels in the $n p c 1^{-l-}$ mice were essentially identical to those seen in the $n p c 1^{+/+}$control animals administered either aCSF or HP- $\beta$-CD. Together, these histological and molecular findings are consistent with the conclusion that continuous cyclodextrin infusion into the CNS fully normalizes the flow of $\mathrm{C}$ through the late $\mathrm{E} / \mathrm{L}$ compartment of neurons in the $n p c 1^{-1-}$ mice, and prevents neurodegeneration.

\section{Discussion}

These studies provide direct support, in vivo, that the two models illustrated in Figure 1 accurately describe the critical differences in cholesterol metabolism in neurons of the CNS and cells of the remaining systemic tissues. Systemic organs like liver take up plasma lipoproteins containing both $\mathrm{C}$ and $\mathrm{CE}$ and, so, require both LAL (Fig. 1 $A a$ ) to hydrolyze the sterol esters and NPC1 $(c)$ to move the liberated $C$ to the site of exit $(d)$ from the late $\mathrm{E} / \mathrm{L}$ compartment. In the normal adult mouse on a low-cholesterol diet, the amount of $\mathrm{C}$ and $\mathrm{CE}$ passing through this pathway each day in all cells of the systemic compartment equals $\sim 140 \mathrm{mg} / \mathrm{kg}$ of body weight (Dietschy, 2009). Inactivation of either of these proteins leads to massive sequestration of $\mathrm{C}$ or $\mathrm{CE}$ in the liver, marked hepatomegaly, and hepatocyte damage (Fig. 2). In contrast, cells of the CNS compartment apparently take up only $\mathrm{C}$, presumably complexed to apoE (Fig. 1B) (Mauch et al., 2001; Hayashi et al., 2004). In the normal mouse, the amount of sterol flowing through this pathway each day equals $\sim 1.4 \mathrm{mg} / \mathrm{kg}$ of body weight, and this is excreted from the CNS into the plasma either as $24(S)$ hydroxycholesterol $(65 \%$, Fig. $1 \mathrm{Bm})$ or, presumably, as C (35\%, Fig. $1 \mathrm{Bl}$ ) (Xie et al., 2003). Similar net excretion of 24( S)hydroxycholesterol from the brain of humans also has been reported (Lütjohann et al., 1996). Therefore, $\mathrm{C}$ is sequestered in neurons when NPC1 is mutated, but not when the activity of LAL is lost. As a result, the $n p c 1^{-/-}$mice, but not the $\mathrm{lal}^{-1-}$ animals, manifest changes in brain biochemistry and markers of inflammation (Fig. 2), as well as $\mathrm{C}$ sequestration in neurons and severe neurodegeneration, particularly in the cerebellum (Fig. 3).

If this sequestration of sterol is causally related to the death of cells in both the systemic and CNS compartments, then manipulation of the amount of $\mathrm{C}$ or $\mathrm{CE}$ that accumulates should alter the level of organ damage. Insofar as data are available, this is the case. When the amount of cholesterol reaching the liver is either reduced or increased, there is either less or more sterol sequestered, and, correspondingly, there is either less or more severe liver cell damage (Beltroy et al., 2007). Similarly, enhancing loss of sterol from the CNS compartment by activating the liver $\mathrm{X}$ receptor system leads to less $\mathrm{C}$ sequestration in neurons, a reduction in microglial activation and markers of inflammation, and a corresponding reduction in the level of neurodegeneration (Repa et al., 2007). Unfortunately, however, it is impossible to totally block cholesterol uptake into cells, and in the brain, such a manipulation, even if available, would presumably be deleterious since neurons require this exogenous, glial-derived supply of $\mathrm{C}$ to promote axon growth and synapse formation (Posse De Chaves et al., 2000; Mauch et al., 2001). Recently, however, it was dem- 
onstrated that HP- $\beta$-CD is able to overcome the transport defect in nearly all tissues throughout the systemic compartment of $n p c 1^{-1-}$ mice, restoring flow of $\mathrm{C}$ through the late $\mathrm{E} / \mathrm{L}$ compartment of these cells to the normal rate of $\sim 140 \mathrm{mg} \cdot \mathrm{kg}^{-1} \cdot \mathrm{d}^{-1}$ (Liu et al., 2009; Liu et al., 2010).

Virtually every cell continuously takes up solute molecules and bulk water from the pericellular fluid by the processes of receptor-mediated and bulk-phase endocytosis. These vesicles move to the late $\mathrm{E} / \mathrm{L}$ compartment where some of the solutes may be metabolized while the bulk-phase water cycles back to the pericellular fluid compartment. Thus, any solute molecule, like sucrose, inulin, dextrin, or cyclodextrin, that is heavily hydrogenbonded into the bulk-phase water is carried into the late $\mathrm{E} / \mathrm{L}$ compartment (Liu et al., 2007; Rosenbaum et al., 2010). When NPC1 is mutated, this late $\mathrm{E} / \mathrm{L}$ compartment is transformed into a complex vesicular structure containing large amounts of $\mathrm{C}$ and other amphipathic lipids like sphingomyelin, complex gangliosides, and bis(monoacylglycerol)phosphate (Gondré-Lewis et al., 2003; Chevallier et al., 2008; Li et al., 2008). The volume of bulk water in this compartment, i.e., the sucrose space, is doubled in size (Neufeld et al., 1999), and its fractional recycling rate back to the pericellular fluid is reduced by half (Neufeld et al., 1999; Goldman and Krise, 2010). As a consequence, the absolute rate of bulk water flow into and out of the $\mathrm{E} / \mathrm{L}$ compartment is unchanged and, in the liver and other systemic organs, equals $\sim 10$ $\mu \mathrm{l} \cdot \mathrm{h}^{-1} \cdot \mathrm{g}^{-1}$ of tissue (Liu et al., 2007). Thus, any molecule like $\mathrm{HP}-\beta$-CD present in the pericellular fluid will be cycled through the $\mathrm{E} / \mathrm{L}$ compartment at a concentration essentially equal to that in the extracellular fluid compartment. These and previous studies indicate that the concentration of HP- $\beta$-CD necessary to effectively reverse the transport defect in cells of either the systemic or CNS compartments is $<1 \mathrm{~mm}$ and, likely, is in the range of only 100-400 $\mu \mathrm{M}$ (Liu et al., 2010).

When given systemically, HP- $\beta$-CD crosses the blood-brain barrier at only very low rates in mature animals. Based on relative $\mathrm{ED}_{50}$ values, the rate of penetration of this molecule from the plasma to the brain extracellular space is $<0.2 \%$ of its rate of movement from the plasma to the liver pericellular bulk water (Ramirez et al., 2011). Nevertheless, when given systemically, HP- $\beta$-CD does partially slow the rate of cerebellar neurodegeneration (Fig. 7K) (Davidson et al., 2009; Ramirez et al., 2010). However, the current studies reveal that the cyclodextrin is far more effective in reversing the lysosomal transport defect when delivered directly into the brain. While systemically delivered HP- $\beta$-CD becomes distributed into an extracellular volume of $\sim 232 \mathrm{ml} / \mathrm{kg}$, when delivered into the CNS, it enters an extracellular space of only $\sim 4 \mathrm{ml} / \mathrm{kg}$ (Johanson et al., 2008; Syková and Nicholson, 2008). Since molecules the size of HP- $\beta$-CD readily move through the extracellular fluid of the brain with diffusion coefficients of $\sim 2 \times 10^{-6} \mathrm{~cm}^{2} / \mathrm{s}$ (Syková and Nicholson, 2008; Thorne et al., 2008), they presumably reach the pericellular fluid surrounding every glial cell and neuron, and are available for uptake through bulk-phase endocytosis.

Thus, $24 \mathrm{~h}$ after the acute intracerebroventricular administration of this compound there is suppression of cholesterol synthesis and an increase in CE formation (Fig. $4 D, F$ ), suppression of many SREBP2 target genes (Fig. $5 A-D$ ), and activation of several LXR-controlled genes (Fig. 5F, G). These metabolic and molecular changes are seen in all regions of the brain, even in those remote from the site of administration (Fig. $6 \mathrm{C}$ ). These findings are identical to those seen in liver following systemic HP- $\beta$-CD administration, and provide unequivocal support for the concept that this compound overcomes the transport defect in the late $\mathrm{E} / \mathrm{L}$ compartment of cells of the brain in the $n \mathrm{pcl}^{-/-}$mice. The $\mathrm{C}$ sequestered in the late $\mathrm{E} / \mathrm{L}$ compartment of these cells has flowed into the metabolically active pool in the cytosolic compartment and activated the appropriate metabolic and regulatory responses. No such responses are seen in the $\mathrm{npcl}^{+/+}$animals since the pool of $\mathrm{C}$ in the lysosomal membranes of these mice normally is kept very low when NPC1 is functioning (Figs. 4, 5) (Möbius et al., 2003). As the concentration of HP- $\beta$-CD is presumably low in the bulk-phase water of the late $\mathrm{E} / \mathrm{L}$ compartment, and as other cyclodextrins incapable of solubilizing cholesterol can still overcome this transport defect, it has been postulated that the HP$\beta$-CD exerts its therapeutic effect by interacting with $\mathrm{C}$ at the membrane interface, partially lifting the sterol out of the bilayer and facilitating its rate of lateral diffusion toward the exit site (Ramirez et al., 2011).

Regardless of the mechanism of action, however, it is clear that in the presence of HP- $\beta$-CD, C flow through the late $\mathrm{E} / \mathrm{L}$ compartment of cells in the systemic organs (Ramirez et al., 2010) and brain is restored to normal, even though NPC1 is nonfunctional. In the brain there are no longer vesicular lipid accumulations in neurons (Fig. $7 M$ ), no changes in mRNA levels of genes controlled by SREBP and LXR (Fig. 8), and no histological evidence of neurodegeneration, particularly in the cerebellum (Fig. $7 \mathrm{~N}, \mathrm{O}$ ), of the $n p \mathrm{cl}^{-1-}$ mice. Apparently, the presence of the $\mathrm{HP}-\beta-\mathrm{CD}$ has restored normal $\mathrm{C}$ flux through the cells of the CNS in the mutant mice, a conclusion further supported by the normal mRNA expression of apoE and CYP46A1 (Fig. 8), proteins that could conceivably be involved in the net movement of $\mathrm{C}$ out of the CNS and into the plasma.

Finally, since cyclodextrins are apparently nontoxic, and have been given to humans, these findings raise the possibility that such compounds might be useful therapeutically in ameliorating or preventing human NPC disease, including both the hepatic dysfunction and neurodegeneration. As the $\mathrm{ED}_{50}$ values for these compounds are known, and as the relative differences in C uptake into cells of the systemic and CNS compartments in humans and mice are published, it should be possible to formulate reasonable protocols for the effective, chronic therapy of this serious lysosomal storage disease. Unfortunately, however, at this time, the critical experiments to show that cyclodextrins actually reverse the transport defect in human NPC disease, as they do in the $n p c 1^{-1-}$ mouse, have not yet been done.

\section{References}

Beltroy EP, Liu B, Dietschy JM, Turley SD (2007) Lysosomal unesterified cholesterol content correlates with liver cell death in murine NiemannPick type C disease. J Lipid Res 48:869-881.

Carstea ED, Morris JA, Coleman KG, Loftus SK, Zhang D, Cummings C, Gu J, Rosenfeld MA, Pavan WJ, Krizman DB, Nagle J, Polymeropoulos MH, Sturley SL, Ioannou YA, Higgins ME, Comly M, Cooney A, Brown A, Kaneski CR, Blanchette-Mackie EJ, et al. (1997) Niemann-Pick C1 disease gene: homology to mediators of cholesterol homeostasis. Science 277:228-231.

Cavender CP, Turley SD, Dietschy JM (1995) Sterol metabolism in fetal, newborn, and suckled lambs and their response to cholesterol after weaning. Am J Physiol 269:E331-E340.

Chevallier J, Chamoun Z, Jiang G, Prestwich G, Sakai N, Matile S, Parton RG, Gruenberg J (2008) Lysobisphosphatidic acid controls endosomal cholesterol levels. J Biol Chem 283:27871-27880.

Davidson CD, Ali NF, Micsenyi MC, Stephney G, Renault S, Dobrenis K, Ory DS, Vanier MT, Walkley SU (2009) Chronic cyclodextrin treatment of murine Niemann-Pick C disease ameliorates neuronal cholesterol and glycosphingolipid storage and disease progression. PLoS One 4:e6951.

Dietschy JM (2009) Central nervous system: cholesterol turnover, brain development and neurodegeneration. Biol Chem 390:287-293.

Dietschy JM, Turley SD (2004) Cholesterol metabolism in the central ner- 
vous system during early development and in the mature animal. J Lipid Res 45:1375-1397.

Dietschy JM, Turley SD, Spady DK (1993) Role of liver in the maintenance of cholesterol and low density lipoprotein homeostasis in different animal species, including humans. J Lipid Res 34:1637-1659.

Du H, Cameron TL, Garger SJ, Pogue GP, Hamm LA, White E, Hanley KM, Grabowski GA (2008) Wolman disease/cholesteryl ester storage disease: efficacy of plant-produced human lysosomal acid lipase in mice. J Lipid Res 49:1646-1657.

German DC, Quintero EM, Liang CL, Ng B, Punia S, Xie C, Dietschy JM (2001) Selective neurodegeneration, without neurofibrillary tangles, in a mouse model of Niemann-Pick C disease. J Comp Neurol 433:415-425.

Goldman SD, Krise JP (2010) Niemann-Pick C1 functions independently of Niemann-Pick C2 in the initial stage of retrograde transport of membrane-impermeable lysosomal cargo. J Biol Chem 285:4983-4994.

Gondré-Lewis MC, McGlynn R, Walkley SU (2003) Cholesterol accumulation in NPC1-deficient neurons is ganglioside dependent. Curr Biol 13:1324-1329.

Hayashi H, Campenot RB, Vance DE, Vance JE (2004) Glial lipoproteins stimulate axon growth of central nervous system neurons in compartmented cultures. J Biol Chem 279:14009-14015.

Johanson CE, Duncan JA 3rd, Klinge PM, Brinker T, Stopa EG, Silverberg GD (2008) Multiplicity of cerebrospinal fluid functions: New challenges in health and disease. Cerebrospinal Fluid Res 5:10.

Karten B, Vance DE, Campenot RB, Vance JE (2002) Cholesterol accumulates in cell bodies, but is decreased in distal axons, of Niemann-Pick C1-deficient neurons. J Neurochem 83:1154-1163.

Karten B, Hayashi H, Francis GA, Campenot RB, Vance DE, Vance JE (2005) Generation and function of astroglial lipoproteins from Niemann-Pick type C1-deficient mice. Biochem J 387:779-788.

Kurrasch DM, Huang J, Wilkie TM, Repa JJ (2004) Quantitative real-time polymerase chain reaction measurement of regulators of G-protein signaling mRNA levels in mouse tissues. Methods Enzymol 389:3-15.

Li H, Repa JJ, Valasek MA, Beltroy EP, Turley SD, German DC, Dietschy JM (2005) Molecular, anatomical, and biochemical events associated with neurodegeneration in mice with Niemann-Pick type C disease. J Neuropathol Exp Neurol 64:323-333.

Li H, Turley SD, Liu B, Repa JJ, Dietschy JM (2008) GM2/GD2 and GM3 gangliosides have no effect on cellular cholesterol pools or turnover in normal or NPC1 mice. J Lipid Res 49:1816-1828.

Liu B, Xie C, Richardson JA, Turley SD, Dietschy JM (2007) Receptormediated and bulk-phase endocytosis cause macrophage and cholesterol accumulation in Niemann-Pick C disease. J Lipid Res 48:1710-1723.

Liu B, Li H, Repa JJ, Turley SD, Dietschy JM (2008) Genetic variations and treatments that affect the lifespan of the NPC1 mouse. J Lipid Res 49:663-669.

Liu B, Turley SD, Burns DK, Miller AM, Repa JJ, Dietschy JM (2009) Reversal of defective lysosomal transport in NPC disease ameliorates liver dysfunction and neurodegeneration in the $n p \mathrm{pl}^{-1-}$ mouse. Proc Natl Acad Sci U S A 106:2377-2382.

Liu B, Ramirez CM, Miller AM, Repa JJ, Turley SD, Dietschy JM (2010) Cyclodextrin overcomes the transport defect in nearly every organ of NPC1 mice leading to excretion of sequestered cholesterol as bile acid. J Lipid Res 51:933-944.

Loftus SK, Morris JA, Carstea ED, Gu JZ, Cummings C, Brown A, Ellison J, Ohno K, Rosenfeld MA, Tagle DA, Pentchev PG, Pavan WJ (1997) Murine model of Niemann-Pick C disease: mutation in a cholesterol homeostasis gene. Science 277:232-235.

Lütjohann D, Breuer O, Ahlborg G, Nennesmo I, Sidén Å, Diczfalusy U,
Björkhem I (1996) Cholesterol homeostasis in human brain: evidence for an age-dependent flux of 24S-hydroxycholesterol from the brain into the circulation. Proc Natl Acad Sci U S A 93:9799-9804.

Mauch DH, Nägler K, Schumacher S, Göritz C, Müller EC, Otto A, Pfrieger FW (2001) CNS synaptogenesis promoted by glia-derived cholesterol. Science 294:1354-1357.

Möbius W, van Donselaar E, Ohno-Iwashita Y, Shimada Y, Heijnen HF, Slot JW, Geuze HJ (2003) Recycling compartments and the internal vesicles of multivesicular bodies harbor most of the cholesterol found in the endocytic pathway. Traffic 4:222-231.

Neufeld EB, Wastney M, Patel S, Suresh S, Cooney AM, Dwyer NK, Roff CF, Ohno K, Morris JA, Carstea ED, Incardona JP, Strauss JF 3rd, Vanier MT, Patterson MC, Brady RO, Pentchev PG, Blanchette-Mackie EJ (1999) The Niemann-Pick $\mathrm{C} 1$ protein resides in a vesicular compartment linked to retrograde transport of multiple lysosomal cargo. J Biol Chem 274:9627-9635.

Nieweg K, Schaller H, Pfrieger FW (2009) Marked differences in cholesterol synthesis between neurons and glial cells from postnatal rats. J Neurochem 109:125-134.

Pfrieger FW (2003) Cholesterol homeostasis and function in neurons of the central nervous system. Cell Mol Life Sci 60:1158-1171.

Pieper AA, Wu X, Han TW, Estill SJ, Dang Q, Wu LC, Reece-Fincanon S, Dudley CA, Richardson JA, Brat DJ, McKnight SL (2005) The neuronal PAS domain protein 3 transcription factor controls FGF-mediated adult hippocampal neurogenesis in mice. Proc Natl Acad Sci USA 102:14052-14057.

Posse De Chaves EI, Vance DE, Campenot RB, Kiss RS, Vance JE (2000) Uptake of lipoproteins for axonal growth of sympathetic neurons. J Biol Chem 275:19883-19890.

Quan G, Xie C, Dietschy JM, Turley SD (2003) Ontogenesis and regulation of cholesterol metabolism in the central nervous system of the mouse. Brain Res Dev Brain Res 146:87-98.

Ramirez CM, Liu B, Taylor AM, Repa JJ, Burns DK, Weinberg AG, Turley SD, Dietschy JM (2010) Weekly cyclodextrin administration normalizes cholesterol metabolism in nearly every organ of the Niemann-Pick type C1 mouse and markedly prolongs life. Pediatr Res 68:309-315.

Ramirez CM, Liu B, Aqul A, Taylor AM, Repa JJ, Turley SD, Dietschy JM (2011) Quantitative role of LAL, NPC2, and NPC1 in lysosomal cholesterol processing defined by genetic and pharmacological manipulations. J Lipid Res 52:688-698.

Repa JJ, Turley SD, Quan G, Dietschy JM (2005) Delineation of molecular changes in intrahepatic cholesterol metabolism resulting from diminished cholesterol absorption. J Lipid Res 46:779-789.

Repa JJ, Li H, Frank-Cannon TC, Valasek MA, Turley SD, Tansey MG, Dietschy JM (2007) Liver X receptor activation enhances cholesterol loss from the brain, decreases neuroinflammation, and increases survival of the NPC1 mouse. J Neurosci 27:14470-14480.

Rosenbaum AI, Zhang G, Warren JD, Maxfield FR (2010) Endocytosis of beta-cyclodextrins is responsible for cholesterol reduction in NiemannPick type C mutant cells. Proc Natl Acad Sci U S A 107:5477-5482.

Syková E, Nicholson C (2008) Diffusion in brain extracellular space. Physiol Rev 88:1277-1340.

Thorne RG, Lakkaraju A, Rodriguez-Boulan E, Nicholson C (2008) In vivo diffusion of lactoferrin in brain extracellular space is regulated by interactions with heparan sulfate. Proc Natl Acad Sci U S A 105:8416-8421.

Xie C, Lund EG, Turley SD, Russell DW, Dietschy JM (2003) Quantitation of two pathways for cholesterol excretion from the brain in normal mice and mice with neurodegeneration. J Lipid Res 44:1780-1789. 